\title{
EFFECT OF TEMPERATURE ON THE FREQUENCY OF CHROMOSOME ABERRATIONS AND MICRONUCLEI IN CULTURED CHINESE HAMSTER CELLS
}

\author{
Shougo ASANAMI, Kazuyuki SHIMONO and Shinya KANEDA \\ Naruto Research Institute, Otsuka Pharmaceutical Factory, Inc., \\ 115 Muya-cho, Naruto, Tokushima 772-8601, Japan
}

(Received February 20, 2001; Accepted September 17, 2001)

\begin{abstract}
We previously reported that both hyperthermia and hypothermia induced micronuclei in mouse bone marrow cells (Asanami and Shimono, 1997a, 1997b, 1999). To investigate the effects of temperature on chromosome aberration in vitro, we conducted chromosome aberration and micronucleus tests under hyper- and hypothermic conditions using Chinese hamster lung (CHL) cells. In the chromosome aberration test, we observed positive responses at $40^{\circ} \mathrm{C}$ and $41^{\circ} \mathrm{C}$ for $24 \mathrm{hr}$, and at $42^{\circ} \mathrm{C}$ for $6 \mathrm{hr}$ and over. In the micronucleus test, we observed positive responses at $31^{\circ} \mathrm{C}, 33^{\circ} \mathrm{C}$, and $40^{\circ} \mathrm{C}$ for $24 \mathrm{hr}$, and at $42^{\circ} \mathrm{C}$ for $2 \mathrm{hr}$. The results suggest that in CHL cells, hypothermic conditions can induce micronuclei while hyperthermic conditions can induce both chromosome aberrations and micronuclei.
\end{abstract}

KEY WORDS: In vitro chromosome aberration test, In vitro micronucleus test, Temperature, Chinese hamster lung cells

\section{INTRODUCTION}

Chromosome aberration (CA) tests using cultured mammalian cells have been widely used in evaluating the clastogenicity of chemicals. Micronuclei (MN) are caused by chromosome breakage and disturbance of the mitotic apparatus (Heddle, 1973; Schmid, 1973; Krishna and Hayashi, 2000). The MN assay, therefore, detects both clastogenicity (chromosome breakage) and aneugenicity (alteration of chromosome number due to chromosome lagging that results from dysfunction of the mitotic apparatus) when performed appropriately (Krishna and Hayashi, 2000). Recently, the in vitro MN test could be an alternative to the CA test for screening the genotoxicity of chemicals.

Heat treatment exerts numerous effects on mammalian cells, including chromosome aberrations (Dewey et al., 1971), alterations in chromosomal proteins (Tomasovic et al., 1978), inhibition of DNA repair (Jorritsma and Konings, 1983), damage to membranes (Yatvin, 1977) and the mitotic apparatus (Dewey et al., 1971), and MN induction (Komae et al., 1999). We found no reports, however, regarding the effects of hypothermic conditions on CA or MN induction in mammalian cells, although we previously reported that both elevated and depressed body temperature induced MN in mouse bone marrow cells (Asanami and Shimono, 1997a, 1997b, 1999). We therefore confirmed the effects of hyper- and hypothermic conditions on induction of $\mathrm{CA}$ and $\mathrm{MN}$ in vitro.

\section{MATERIALS AND METHODS}

\section{Cells}

CHL/IU cells were obtained from the National Institute of Health Sciences. They were maintained in Eagle's minimum essential medium supplemented with $10 \%$ heat-inactivated $\left(56^{\circ} \mathrm{C}\right.$ for $\left.30 \mathrm{~min}\right)$ calf serum.

\section{Chromosome aberration test}

$2 \times 10^{4}$ cells were seeded in $60 \mathrm{~mm}$ plastic plates, treated 3 days later at $31,33,40,41$, or $42^{\circ} \mathrm{C}$ for $1,2,3$, 6 , or $24 \mathrm{hr}$, and then cultured in fresh medium at $37^{\circ} \mathrm{C}$ for another 23, 22, 21, 18, or $0 \mathrm{hr}$, respectively. Slides were prepared as described by Sofuni et al. (1990), with minor modifications. Briefly, colcemid (final con- 
centration $0.2 \mathrm{mg} / \mathrm{mL}$ ) was added to the culture for $2 \mathrm{hr}$ before cell harvesting. The harvested cells were trypsinized and incubated in $0.075 \mathrm{M} \mathrm{KCl}$ hypotonic solution for $15 \mathrm{~min}$ at $37^{\circ} \mathrm{C}$ and fixed 3 times with icecold 1:3 acetic alcohol. A drop of cell suspension was placed on a clean glass slide, air-dried, and stained with Giemsa solution. All slides were coded, and 100 or 200 well-spread mitotic metaphases were analyzed. The frequencies of cells with chromosome aberrations were recorded together with types of aberrations (chromatid or chromosome gap, break, exchange, polyploidy, etc).

\section{Micronucleus test}

$5 \times 10^{4}$ cells were seeded in $60 \mathrm{~mm}$ plastic plates, treated 2 days later at $31,33,40$, or $42^{\circ} \mathrm{C}$ for $1,2,3,6$, or $24 \mathrm{hr}$, and then cultured with fresh medium at $37^{\circ} \mathrm{C}$ for another $47,46,45,42$, or $24 \mathrm{hr}$, respectively. We conducted the in vitro $\mathrm{MN}$ test as described by Matsuoka et al. (1993). Briefly, after heat treatment, the cells were treated with trypsin supplemented with EDTA to make a single cell suspension and incubated in hypotonic $(0.075 \mathrm{M}) \mathrm{KCl}$ solution for $10 \mathrm{~min}$ at room temperature. The cells were fixed in three or more changes of 1:3 acetic alcohol, then suspended in methanol containing $1 \%$ acetic acid. A drop of cell suspension was placed on a clean glass slide and air-dried. The preparation was stained with $40 \mathrm{mg} / \mathrm{mL}$ acridine orange solution and immediately observed by fluorescence microscopy with blue excitation. All slides were coded, and the number of cells with MN was recorded based on the observation of 1000 intact interphase cells. The number of mitotic cells appearing in the same microscopic field was also recorded.

\section{Statistical analysis}

Statistical analysis was performed by comparison with the concurrent negative control $\left(37^{\circ} \mathrm{C}\right.$ treatment group) using Fisher's exact test (Yoshimura, 1987).

\section{RESULTS}

For CA test, hyperthermic conditions $\left(40\right.$ or $41^{\circ} \mathrm{C}$ for $24 \mathrm{hr}, 42^{\circ} \mathrm{C}$ for 6 or $24 \mathrm{hr}$ ) induced a significant increase in structural CA, including chromatid or chromosome gap, chromatid break, chromatid exchange, and fragmentation. Six hr at $42^{\circ} \mathrm{C}$ significantly induced polyploidy. No CA was observed under hypothermic conditions (Table 1).

For MN test, both hyperthermic $\left(40^{\circ} \mathrm{C}\right.$ for $24 \mathrm{hr}$, $42^{\circ} \mathrm{C}$ for $2-24 \mathrm{hr}$ ) and hypothermic $\left(31\right.$ and $32^{\circ} \mathrm{C}$ for $24 \mathrm{hr}$ ) conditions induced a significant increase in $\mathrm{MN}$ frequencies (Table 2).

\section{DISCUSSION}

We demonstrated here that hyperthermic conditions significantly induced both $\mathrm{CA}$ and $\mathrm{MN}$ in cultured CHL cells, while hypothermic conditions significantly induced only MN.

Dewey (1989) reported that the major cellular effects of hyperthermia result primarily from the denaturation and aggregation of proteins in the cell, and there are few DNA single-strand or double-strand breaks induced by heat. We suggested that the mechanism of the MN induction by hyperthermia is a disturbance of the mitotic apparatus (Asanami and Shimono, 1997a) and inhibition of DNA repair (Asanami and Shimono, 1999). Therefore, hyperthermic conditions can induce both structural CA and numerical CA in vitro due to the disruption of protein structures leading to disturbance of the mitotic apparatus and inhibition of enzyme activity associated with DNA repair systems. This would also be responsible for the observed MN induction in this test.

Hypothermia, on the other hand, has not previously been reported to induce CA or MN in vitro. In in vivo studies, Asanami and Shimono (1997b) showed that hypothermia induced $\mathrm{MN}$ in mouse bone marrow cells, and suggested that the mechanism was a disturbance of the mitotic apparatus. In the present study, hypothermic conditions induced $\mathrm{MN}$, but not structural CA. The results suggest that hypothermic conditions (31 and $32^{\circ} \mathrm{C}$ for $24 \mathrm{hr}$ ) may also disrupt the mitotic apparatus, but we speculate that hypothermia may not be strong enough to induce polyploidy as hyperthermia.

In conclusion, we confirmed that both hyper- and hypothermic conditions directly affect CA or MN frequencies in vitro. Hyperthermia and hypothermia, therefore, could directly affect $\mathrm{MN}$ frequencies in vivo. It seems that hyperthermic conditions can induce both structural CA and numerical CA, but a hypothermic condition can produce only aneuploidy in CHL cells.

\section{ACKNOWLEDGMENT}

The authors are grateful to Dr. Miriam Bloom for her critical reading of the manuscript.

\section{REFERENCES}

Asanami, S. and Shimono, K.(1997a): High body temperature induces micronuclei in mouse bone mar- 
Temperature effect on chromosome aberrations and micronucleus induction in vitro.

Table 1. Effects of temperature on the frequency of chromosome aberrations in CHL cells.

\begin{tabular}{|c|c|c|c|c|c|c|c|c|c|c|c|c|}
\hline \multirow{2}{*}{$\begin{array}{c}\text { Temperature } \\
\text { (ㄷ) }\end{array}$} & \multirow{2}{*}{$\begin{array}{c}\text { Treatment } \\
\text {-recovery (hr) }\end{array}$} & \multirow{2}{*}{$\begin{array}{l}\text { No. of cells } \\
\text { analyzed }\end{array}$} & \multirow{2}{*}{$\begin{array}{l}\text { MI } \\
(\%)\end{array}$} & \multicolumn{7}{|c|}{ Number of aberrations } & \multirow[t]{2}{*}{ TAG } & \multirow[t]{2}{*}{ Poly } \\
\hline & & & & gap & $\mathrm{ctb}$ & cte & $\mathrm{csb}$ & cse & other & mult & & \\
\hline \multirow[t]{2}{*}{31} & $0-24$ & 100 & 4.5 & 1 & 1 & 0 & 0 & 0 & 0 & 0 & 2 & 0 \\
\hline & $24-0$ & 200 & 2.3 & 0 & 0 & 0 & 0 & 0 & 0 & 0 & 1 & 0 \\
\hline \multirow[t]{2}{*}{33} & $0-24$ & 100 & 4.7 & 0 & 0 & 0 & 0 & 0 & 0 & 0 & 0 & 0 \\
\hline & $24-0$ & 200 & 3.6 & 1 & 0 & 0 & 0 & 0 & 0 & 0 & 1 & 0 \\
\hline \multirow[t]{6}{*}{40} & $0-24$ & 200 & 6.1 & 1 & 0 & 0 & 0 & 0 & 0 & 0 & 1 & 1 \\
\hline & $1-23$ & 200 & 5.4 & 2 & 0 & 0 & 0 & 0 & 0 & 0 & 2 & 3 \\
\hline & $2-22$ & 200 & 6.7 & 2 & 1 & 0 & 0 & 0 & 0 & 0 & 3 & 1 \\
\hline & $3-21$ & 200 & 6.4 & 3 & 0 & 0 & 0 & 0 & 0 & 0 & 3 & 0 \\
\hline & $6-18$ & 200 & 6.6 & 3 & 2 & 0 & 0 & 0 & 0 & 0 & 5 & 1 \\
\hline & 24-0 & 200 & 4.6 & 3 & 4 & 2 & 0 & 0 & 0 & 0 & $9 * *$ & 3 \\
\hline \multirow[t]{6}{*}{41} & $0-24$ & 200 & 7.0 & 2 & 0 & 0 & 0 & 0 & 0 & 0 & 2 & 1 \\
\hline & $1-23$ & 200 & 7.1 & 1 & 0 & 0 & 0 & 0 & 0 & 0 & 1 & 0 \\
\hline & $2-22$ & 200 & 7.2 & 1 & 0 & 0 & 0 & 0 & 0 & 0 & 1 & 1 \\
\hline & $3-21$ & 200 & 6.2 & 2 & 1 & 0 & 0 & 0 & 0 & 0 & 3 & 1 \\
\hline & $6-18$ & 200 & 7.3 & 2 & 0 & 0 & 0 & 0 & 0 & 0 & 2 & 0 \\
\hline & 24-0 & 200 & 5.2 & 7 & 4 & 5 & 0 & 0 & 0 & 0 & $16^{* *}$ & 0 \\
\hline \multirow[t]{6}{*}{42} & $0-24$ & 200 & 6.6 & 1 & 0 & 0 & 0 & 0 & 0 & 0 & 1 & 2 \\
\hline & $1-23$ & 200 & 5.5 & 3 & 0 & 0 & 0 & 0 & 0 & 0 & 3 & 2 \\
\hline & $2-22$ & 200 & 5.5 & 1 & 1 & 0 & 0 & 0 & 0 & 0 & 2 & 4 \\
\hline & $3-21$ & 200 & 5.9 & 3 & 0 & 1 & 0 & 0 & 0 & 0 & 4 & 8 \\
\hline & $6-18$ & 200 & 5.2 & 2 & 5 & 4 & 0 & 0 & 0 & 0 & $9 * *$ & $10 *$ \\
\hline & 24-0 & 200 & 1.2 & 18 & 49 & 14 & 0 & 0 & 45 & 73 & $173 * *$ & 1 \\
\hline
\end{tabular}

gap, chromatid or chromosome gap; ctb, chromatid break; cte, chromatid exchange; csb, chromosome break; cse, chromosome exchange; other, fragmentation; mult, more than 9 aberrations; TAG total number of aberrant cells including gaps; Poly, polyploidy; MI, Mitotic index (\%);**p<0.01 vs control (Fisher's exact test).

Table 2. Effects of temperature on the micronucleus frequency in CHL cells.

\begin{tabular}{|c|c|c|c|c|c|}
\hline \multirow{2}{*}{$\begin{array}{c}\text { Temperature } \\
\left({ }^{\circ} \mathrm{C}\right)\end{array}$} & \multirow{2}{*}{$\begin{array}{c}\text { Treatment } \\
\text {-recovery (hr) }\end{array}$} & \multirow{2}{*}{$\begin{array}{c}\text { No. of cells } \\
\text { analyzed }\end{array}$} & \multirow{2}{*}{$\begin{array}{l}\text { MI } \\
(\%)\end{array}$} & \multicolumn{2}{|c|}{ Micronuceated cells / 1000 cells } \\
\hline & & & & Individual data & Mean \pm SD (\%o) \\
\hline 31 & $\begin{array}{c}0-48 \\
24-24\end{array}$ & $\begin{array}{l}4000 \\
4000\end{array}$ & $\begin{array}{l}1.9 \\
1.7\end{array}$ & $\begin{array}{l}13,19,16,18 \\
30,43,35,43\end{array}$ & $\begin{array}{ll}16.5 \pm & 2.6 \\
37.8 \pm & 6.4^{* *}\end{array}$ \\
\hline 33 & $\begin{array}{c}0-48 \\
24-24\end{array}$ & $\begin{array}{l}4000 \\
4000\end{array}$ & $\begin{array}{l}1.7 \\
2.3\end{array}$ & $\begin{array}{l}10,11,10,11 \\
49,56,39,54\end{array}$ & $\begin{array}{ll}10.5 \pm & 0.6 \\
49.5 \pm & 7.6^{* *}\end{array}$ \\
\hline 40 & $\begin{array}{c}0-48 \\
1-47 \\
2-46 \\
3-45 \\
6-42 \\
24-24\end{array}$ & $\begin{array}{l}2000 \\
2000 \\
2000 \\
2000 \\
2000 \\
2000\end{array}$ & $\begin{array}{l}2.1 \\
2.0 \\
2.2 \\
1.5 \\
2.3 \\
2.1\end{array}$ & $\begin{array}{l}12,10 \\
14,10 \\
15,11 \\
12,10 \\
15,10 \\
34,47\end{array}$ & $\begin{array}{ll}11.0 \pm & 1.4 \\
12.0 \pm & 2.8 \\
13.0 \pm & 2.8 \\
11.0 \pm & 1.4 \\
12.5 \pm & 3.5 \\
40.5 \pm & 9.2 * *\end{array}$ \\
\hline 42 & $\begin{array}{c}0-48 \\
1-47 \\
2-46 \\
3-45 \\
6-42 \\
24-24\end{array}$ & $\begin{array}{l}2000 \\
2000 \\
2000 \\
2000 \\
2000 \\
2000\end{array}$ & $\begin{array}{l}2.2 \\
1.8 \\
2.4 \\
2.7 \\
2.8 \\
0.8\end{array}$ & $\begin{array}{l}19,8 \\
10,12 \\
17,38 \\
38,41 \\
41,37 \\
251,272\end{array}$ & $\begin{array}{rr}13.5 \pm & 7.8 \\
11.0 \pm & 1.4 \\
27.5 \pm & 14.8^{* *} \\
39.5 \pm & 2.1^{* *} \\
39.0 \pm & 2.8^{* *} \\
261.5 \pm & 14.8^{* *}\end{array}$ \\
\hline
\end{tabular}

MI, Mitotic index $(\%) ; *$ p $<0.01$ vs control (Fisher's exact test). 
row. Mutat. Res., 390, 79-83.

Asanami, S. and Shimono, K. (1997b): Hypothermia induces micronuclei in mouse bone marrow cells. Mutat. Res., 393, 91-98.

Asanami, S. and Shimono, K. (1999): The effect of hyperthermia on micronucleus induction by mutagens in mice. Mutat. Res., 446, 149-154.

Dewey, W.C. (1989): The search for critical cellular targets damaged by heat. Radiat. Res., 120, 191204.

Dewey, W.C., Westra, A., Miller, H.H. and Nagasawa, H. (1971): Heat-induced lethality and chromosomal damage in synchronic Chinese hamster cells treated with 5-bromodeoxyuridine. Int. J. Radiat Biol., 20, 505-520.

Heddle, J.A. (1973): A rapid in vivo test or chromosomal damage. Mutat. Res., 18, 187-190.

Jorritsma, J.B.M. and Konings, A.W.T. (1983): Inhibition of repair of radiation-induced strand breaks by hyperthermia, and its relationship to cell survival after hyperthermia alone, Int. J. Radiat. Biol., 143, 26-33.

Komae, N., Hibino, Y. and Sugano, N. (1999): Analysis of micronuclei induced under hyperthermic conditions in human lymphocyte culture by fluorescence in situ hybridization (FISH) and spectral karyotyping (SKY) methods. Yakugaku Zasshi, 119, 763-772.
Krishna, G. and Hayashi, M. (2000): In vivo rodent micronucleus assay: Protocol, conduct and data interpretation. Mutat. Res., 455, 155-166.

Matsuoka, A., Yamazaki, N., Suzuki, T., Hayashi, M. and Sofuni, T. (1993): Evaluation of the micronucleus test using a Chinese hamster cell line as an alternative to the conventional in vitro chromosome aberration test. Mutat. Res., 272, 223-236.

Schmid, W. (1973): Chemical mutagen testing on in vivo somatic mammalian cells. Agents and Actions, 3, 77-85.

Sofuni, T., Matsushima, A., Shimada, M., Ishidate, M. Jr., Zeiger, E. and Shelby, M.D. (1990): A comparison of chromosome aberration induction by 25 compounds tested by two Chinese hamster cell (CHL and CHO) systems in culture. Mutat. Res., 241, 175-213.

Tomasovic, S.P., Turner, G.N. and Dewey, W.C. (1978): Effect of hyperthermia on nonhistone proteins isolated with DNA. Radiat. Res., 73, 535552.

Yatvin, M.B. (1977): The influence of membrane lipid composition and procaine on hyperthermic death of cells. Int. J. Radiat. Biol., 32, 513-521.

Yoshimura, I. (1987): Statistical analysis of toxicity and drug efficacy data. Scientist Co., Tokyo, pp. 7678 , in Japanese. 